\title{
AKTIVITAS ENZIM PELARUT FOSFAT DAN EFEKTIVITAS MIKROBA ASAL WAMENA UNTUK MENUNJANG PERTANIAN RAMAH LINGKUNGAN PADA DAERAH MARGINAL
}

\author{
Sri Widawati \\ Bidang Mikrobiologi, Puslit Biologi, LIPI \\ Jl.Raya Jakarta-Bogor Km 46 Cibinong (CSC) \\ widadomon@yahoo.com
}

\begin{abstract}
Abstrak
The activity of phosphate solubilizing enzyme and the effectivity of microbe from Wamena for support agriculture of environmental friendliness at marginal area. Phosphate dissolution of enzyme by microbial effective in compost plus from Wamena forest was stored in the freezer for 4 years, have been conducted in Ecofisiology laboratory, Microbiology devision, Research Center for Biology, Indonesian Institute of Science. This research was conducted to know the microbial affectivity and the activity of phosphate solubilizing enzyme of 20 microorganisms in inoculants stored 4 years in refrigerated room and to support soil fertility and biofertilizer agent in organic farming system. This research used plate count methode for counting the amount of microbial population, Scinner method was used toanalizer enzyme of alkaline and acid PME-ase, and statistical analysis use Duncan methode. The storage of 20 inoculants invected 20 microorganisms for 4 years in refrigerated room showed that the microbial activity still high with the amount of mean population 107 and the activity of phosphate solubilizing enzyme with mean diameter of clear zone (holozone) $1 \mathrm{~cm}-2 \mathrm{~cm}$. The effectivity and the highest activity of phosphate solubilizing enzyme were: Azotobacter indicus (A), Bacillus panthothenticus $(D)$, Bacillus megaterium $(M)$, Bacillus thuringiensis $(O)$, Ceratia sp. $(R)$, Chromobacterium lividum (G), Chromobacterium violaceum (S), Flavobacterium breve $(T)$, Klebsiella aerogenes (H), Pseudomonas fluorescent (J), Rhizobium legurxinosarium (L), and the lowest were: Streptomyces sp. (I).
\end{abstract}

Key word: Alkaline and acid PMEase, Phosphate solubilizing bacteria,Biofertolizer

\section{PENDAHULUAN}

\subsection{Latar Belakang}

Alam memiliki kemampuan untuk melakukan reklamasi lahan dan menyediakan berbagai jenis organisma hidup yang dapat dimanfaatkan untuk berbagai keperluan. Beberapa mikroba berpotensi dapat dijadikan sebagai pupuk (biofertilizer) atau kompos plus dalam pembuatan pupuk secara hayati. Peluang pemanfaatan dan pengembangan potensi mikroba cukup relevan dengan kegiatan intensifikasi pertanian yang berbasis teknologi biologi yang ramah lingkungan. Beberapa mikroba berpotensi dapat dimanfaatkan dan dikembangkan sebagai inokulan pembuatan pupuk (biofertilizer) dalam bentuk kompos plus. Mikroorganisma yang bersifat biofertilizer merupakan aset penting dalam system organic farming yang telah diterapkan pada beberapa daerah 
di Indonesi maupun pertanian ramah lingkungan di daerah marginal, dataran tinggi ber iklim ekstrim dan daerah pesisir yang bersalinitas tinggi.

Keberadaan mikroorganisma di alam, khususnya Bakteri Pelarut Fosfat (BPF), Bakteri Penambat Nitrogen simbiotik (BPNS), Bakteri Penambat Nitrogen non Simbiotik (BPNnS), dan Actinomycetes yang mampu melarutkan $P$ terikat sangat penting, karena mempunyai peranan dalam meningkatkan dan menjaga kesuburan tanah. Mikroorganisma juga mempunyai peranan mendaur ulang hara, menyimpan hara sementara, dan melepaskan hara untuk dimanfaatkan tanaman. Mikroorganisma tersebut melepaskan asam yang mampu melarutkan mineral, sehingga unsur hara yang terlarut dapat dimanfaatkan tanaman. Mikroorganisme seperti BPF, BPNS, BPNnS, dan Actinomycetes telah berhasil diisolasi dari sampel tanah di Kebun Biologi Wamena dan hutan Wamena, Papua.

Hasil isolasi dan identifikasi mikroba yang terdahulu yang dilakukan oleh penulis dan kawan-kawan ${ }^{1)}$ adalah : (1). Azospirillum sp.(B), (2). Azotobacter chroococcum (C), (3). Azotobacter indicus (A), (4). Azotobacter paspalii (E), (5). Bacillus panthothenticus (D), (6). Bacillus megaterium (F), (7). Bacillus thuringiensis (0), (8). Cellulomonas flavigena
(K), (9). Ceratia sp.(R), (10). Chromobacterium lividum (G), (11). Chromobacterium violaceum (S), (12). Citrobacter sp. (N), (13). Flavobacterium breve (T), (14). Klebsiella aerogenes $(\mathbf{H}),(15)$. Nitromosomonas mesentrica(P), (16). Pseudomonas fluorescent (J), (17). Rhizobium legurxinosarium (L), (18). Spaerotilus natans (Q), (19). Spirilum lipoferum (M), (20). Streptomyces sp.(I). Efektivitasnya ke 20 jenis mikroba tersebut telah teruji skala laboratorium (aktivitas enzim pelarut fosfat) dan lapangan dalam bentuk kompos plus selama 7 tahun berturut-turut dan menunjukan hasil yang positif dalam memacu pertumbuhan beberapa tanaman tinggi ${ }^{23)}$, sebagai starter pembuatan pupuk hayati dan pematangan kompos lebih cepat serta mengembalikan kesuburan tanah ${ }^{4}$, meningkatkan hasil panen tanaman obat pada tanah masam ${ }^{5,6)}$, memicu pertumbuhan dan hasil panen tanaman sayur-sayuran di tanah marginal dataran tinggi $i^{7,8,9)}$. Hasil analisa fisik dan kimia tanah dari 11 contoh tanah (gambar 1b) dapat dibaca pada Tabel 1.

\subsection{Tujuan}

Percobaan ini dilakukan untuk mengetahui efektivitas mikroba dan aktivitas enzim pelarut fosfat skala laboratorium ke 20 mikroba pada inokulan yang tersimpan

Table 1. Analisa fisik dan kimia pada 11 contoh tanah daerah perakan hutan Wamena

\begin{tabular}{|c|l|l|c|c|c|c|c|c|}
\hline \multirow{2}{*}{ No. } & \multirow{3}{*}{ Warna tanah } & \multirow{3}{*}{ Daerah perakaran tanaman } & \multicolumn{3}{|c|}{ Tekstur (\%) } & \multicolumn{3}{|c|}{$\begin{array}{c}\text { Analisa kimia dan } \\
\text { pH }\end{array}$} \\
\cline { 4 - 9 } & & & debu & Pasir & Liat & $\mathrm{P}(\mathrm{ppm})$ & $\mathrm{C} / \mathrm{N}$ & $\mathrm{pH}$ \\
\hline 1 & Hitam & Imperata cylindrica & 43.01 & 18.03 & 38.06 & 2.1 & 11.0 & 5.26 \\
\hline 2 & Coklat & Imperata cylindrica & 48.61 & 15.65 & 35.74 & 2.7 & 10.7 & 4.25 \\
\hline 3 & Abu-abu & Imperata cylindrica & 49.28 & 10.89 & 38.82 & 1.6 & 9.0 & 4.60 \\
\hline 4 & Merah & Imperata cylindrica & 22.69 & 11.51 & 65.75 & 0.3 & 10.3 & 6.05 \\
\hline 5 & $\begin{array}{l}\text { Coklat } \\
\text { kemerahan }\end{array}$ & Imperata cylindrica & 40.19 & 16.36 & 43.45 & 0.2 & 11.5 & 5.00 \\
\hline 6 & Kuning & Imperata cylindrica & 41.06 & 17.51 & 41.42 & 0.4 & 10.2 & 5.25 \\
\hline 7 & Lime particle & Imperata cylindrica & 45.61 & 35.30 & 16.06 & 0.1 & 12.0 & 4.65 \\
\hline 8 & Hitam & Pittosporum ramiflorum & 42.84 & 5.79 & 51.37 & 4.8 & 12.1 & 5.30 \\
\hline 9 & Coklat & Voccinium varingiaefolium & 55.26 & 16.73 & 28.01 & 3.3 & 16.7 & 4.90 \\
\hline 10 & Coklat & Castanopsis accuminattisima & 61.25 & 20.17 & 18.56 & 1.6 & 14.5 & 4.35 \\
\hline 11 & Coklat gelap & Grevillea papuana & 40.54 & 7.38 & 52.08 & 3.9 & 10.2 & 4.80 \\
\hline
\end{tabular}


selama 4 tahun dalam lemari pendingin. Hasilnya sangat diperlukan untuk pembuatan inokulan/kompos plus selanjutnya yang akan digunakan kembali untuk revegetasi lahan marginal. Percobaan ini sangat penting dalam menunjang keberhasilan System organic farming selanjutnya yang sedang dilakukan di beberapa daerah di Indonesia seperti di daerah puncak, kawasan penyangga gunung salak, Wamena-Papua dan daerah lainnya.

\section{METODOLOGI}

\subsection{Tempat dan Waktu Penelitian}

Penyimpanan kompos plus dalam lemari pendingin dimulai pada tahun 2005 dan empat tahun kemudian (tahun 2008) kompos tersebut dianalisa kembali efektivitas bakteri yang terkandung di dalamnya. Tes tersebut meliputi penghitungan jumlah mikroba dan uji potensi pelarut fosfat mikroba dalam petridish, pengukuran $\mathrm{pH}$ dan aktivitas PMEase - asam dan basa dan pengukuran Fosfat Bebas. Tes-tes tersebut dilakukan di laboratorium Ekofisiologi, Bidang Mikrobiologi, Puslit Biologi, LIPI.

\subsection{Penghitungan jumlah mikroba dan uji potensi pelarut fosfat mikroba dalam Petridish ${ }^{10}$}

Sepuluh gram kompos plus dari masingmasing kompos plus yang mengandung jenis - jenis bakteri (20 jenis bakteri) yang telah tersimpan 2 tahun dalam lemari pendingin dimasukkan ke $90 \mathrm{ml}$ aquades steril dan dishaker selama 1 jam dengan kecepatan $120 \mathrm{rpm}$. Satu mili ekstrak dimasukkan dalam tabung berisi $9 \mathrm{ml}$ aquadest steril, di kocok hingga homogen dan 1 mili dipindahkan ke tabung berikutnya, lakukan hal serupa hingga mencapai pengenceran 10-7. Kemudian sebanyak 0,2 ml ekstrak pengenceran (10-3, 10-5, 10-7) dimasukkan ke petridish steril dan tuangkan media selektif (Pikokvskaya untuk bakteri pelarut fosfat, Manitol ashby untuk Azotobacter , Okon untuk Azospirillum, serta Humic Acid Vitamin/HV dan Yeast Strach Agar/YSA untuk Actinomycetes), lalu diinkubasi selama 3-7 hari pada suhu $280 \mathrm{C}$. Jumlah populasi bakteri dari masing-masing media selektif dihitung menurut metode plate count (Rao, 1994). Koloni dari masing - masing mikroba (BPNS, BPNnS, BPF, dan

Actinomycetes) di transfer ke media pertumbuhan pikovskaya, yaitu: $10 \mathrm{~g}$ glukosa; 5 g Ca3PO4; 0,5 g (NH4)2SO4; $0,2 \mathrm{~g} \mathrm{KCl} ; 0,1 \mathrm{~g} \mathrm{MgSO} 4$ 7H20; 0,01 g MnSO4 H2O; 0,5 g yeast ekstrak dan $0,01 \mathrm{~g} \mathrm{FeCl} 36 \mathrm{H} 2 \mathrm{O}$ pada $\mathrm{pH} 7$ (Rao, 1994). Tujuannya dilakukan hal tersebut adalah untuk mengetahui aktivitas mikroba pelarut fosfat yang ditentukan berdasarkan pembentukan zona bening (holozone area) pada medium pikovskaya. Pengukuran yang dilakukan berupa ratio zona bening dengan membandingkan diameter zona bening dan diameter koloni setelah diinkubasi 7 hari pada temperatur ruang.

\subsection{Pengukuran $\mathrm{pH}$ dan aktivitas PMEase - asam dan basa ${ }^{11)}$}

Asiditas kultur dan supernatan diukur secara langsung dengan menggunakan $\mathrm{pH}$ meter. Pengukuran aktivitas PME-ase dilakukan dengan cara : Larutan standar p-nitrofenol (0,1 gram p-nitrofenol dilarutkan dalam air suling, diencerkan sampai volume $100 \mathrm{~mL}$ dalam labu takar, yaitu larutan induk $1000 \mu \mathrm{g}$ p-nitrofenol mL-1). Dibuat larutan standar $20 \mu \mathrm{g}$ p-nitrofenol $\mathrm{mL}-1$ dengan cara memipet $2 \mathrm{~mL}$ larutan induk ke dalam labu takar $100 \mathrm{~mL}$, lalu ditambahkan air suling sampai tanda tera. Dipipet 0, 1, 2, 3, 4 dan $5 \mathrm{~mL}$ larutan standar $20 \mu \mathrm{g}$-nitrofenol $\mathrm{mL}-1$ kedalam tabung reaksi, diencerkan dalam air suling sampai volume $5 \mathrm{~mL}$. Kemudian ditambah $1 \mathrm{~mL}$ kalsium klorida 0,5 M dan $4 \mathrm{~mL}$ natrium hidroksida 0,5 M. Diaduk sampai homogen, diukur absorbannya dengan spektrofotometer pada panjang gelombang $400 \mathrm{~nm}$. Selanjutnya untuk cara 
pengujian aktivitas fosfomonoesterase yaitu: Satu $\mathrm{mL}$ kultur cair mikroba dimasukan dalam botol uji, ditambahkan $1 \mathrm{~mL}$ substrat p-nitrofenilfosfat $20 \mu \mathrm{g}$ p-nitrofenol $\mathrm{mL}-1$ dan $4 \mathrm{~mL}$ buffer yang ber $\mathrm{pH}$ 6,5 untuk PMEaseasam dan ber $\mathrm{pH} 7,5$ untuk PMEase-basa. Kemudian dikocok, ditutup, dan diinkubasi pada suhu $370 \mathrm{C}$ selama1 jam. Setelah inkubasi ditambahkan $1 \mathrm{~mL} \mathrm{CaCl2} \mathrm{0,5} \mathrm{M}$ dan $4 \mathrm{~mL} \mathrm{NaOH} \mathrm{0,5} \mathrm{M}$, dikocok dan disaring. Dipipet $1 \mathrm{~mL}$ filtrat ke dalam tabung reaksi dan tambahkan $9 \mathrm{~mL}$ air suling, lalu diukur absorbannya dengan spektrofotometer pada panjang gelombang $400 \mathrm{~nm}$. Setiap contoh diulang 3 kali. Sebagai kontrol digunakan akuades steril.

\subsection{Pengukuran Fosfat Bebas ${ }^{12)}$}

Reagent yang digunakan dalam analisis fosfat bebas adalah :H2SO4 $5 \mathrm{~N}=14 \mathrm{~mL}$ $\mathrm{H} 2 \mathrm{SO} 4$ diencerkan menjadi $100 \mathrm{~mL}$ dengan akuades (larutan $\mathrm{A}), 0,324 \mathrm{~g}(\mathrm{~K}(\mathrm{Sb} \mathrm{O}) \mathrm{C} 4$ $\mathrm{H} 4 \mathrm{O} 6.1 / 2 \mathrm{H} 2 \mathrm{O}$ ) dilarutkan dalam akuades sehingga volume menjadi $100 \mathrm{~mL}$ (larutan $\mathrm{B}$ ), $4 \mathrm{~g}$ (NH4)2Mo7O24 dilarutkan dalam akuades sehingga volume menjadi100 $\mathrm{mL}$ (larutan C), 1,76 g Asam Askorbat dilarutkan dalam akuades sehingga volume menjadi $100 \mathrm{~mL}$ (larutan D). Reagen tersebut dicampurkan dengan mengambil $10 \mathrm{~mL}$ larutan $A+1$ $\mathrm{mL}$ larutan $\mathrm{B}+3 \mathrm{~mL}$ larutan $\mathrm{C}+6 \mathrm{~mL}$ larutan $\mathrm{D}$, campuran tersebut kemudian dikocok hingga homogen. Selanjutnya 5 gram sampel disentrifuse selama 10 menit,kemudian kedalam $3 \mathrm{~mL}$ supernatan hasil sentrifugasi ditambahkan $0,5 \mathrm{~mL}$ campuran reagent $(A+B+C+D)$ dan diinkubasi selama 15-30 menit. Fosfat bebas diukur dengan menggunakan spektrofotometer pada panjang gelombang $880 \mathrm{~nm}$. Untuk standarisasi digunakan $\mathrm{KH}_{2} \mathrm{PO}_{4}$ yang dibuat berdasarkan ppm yang diinginkan.

\section{HASIL DAN PEMBAHASAN}

Dua puluh jenis mikroba A sampai $T$ (Tabel 2) yang terkandung dalam inokulan
"AZZOFOR" (Gambar 1a) hasil isolasi dari tanah perakaran tanaman hutan di wamena (Gambar 1b), setelah tersimpan selama 4 tahun (bentuk inokulan) dalam lemari pendingin, menunjukan penurunan jumlah populasi dari rata-rata $10^{9} \mathrm{sel} /$ gram pada 0 tahun menjadi rata-rata $10^{7}$ (Tabel 2). Jumlah populasi tersebut masih termasuk dalam standar kemampuan mikroba sebagai agen biofertilizer ${ }^{13)}$, jadi masih dapat untuk digunakan sebgai pupuk hayati. Seluruh mikroba tersebut juga masih mampu melakukan solubilisasi kalsium fosfat seperti diindikasikan dengan terbentuknya zona bening (holozone) disekitar koloni yang sedang tumbuh (Tabel 2 dan Gambar 3). Holozone terjadi karena adanya pelarutan partikel halus dari $\mathrm{Ca}_{2}\left(\mathrm{PO}_{4}\right)_{2}$. Luasnya holozone juga mengindikasikan besar kecilnya kemampuan mikroba dalam melarutkan $P$ terikat ${ }^{14)}$. Hasil pengamatan dari ke 20 mikroba tersebut, ternyata Azotobacter indicus (A), Bacillus panthothenticus (D), Bacillus megaterium (F), Bacillus thuringiensis (O), Ceratia sp. (R), Chromobacterium lividum (G), Chromobacterium violaceum (S), Flavobacterium breve (T), Klebsiella aerogenes (H), Pseudomonas fluorescent (J), Rhizobium leguminosorum (L), menghasilkan zona bening lebih luas dibandingkan bakteri pelarut fosfat dan penambat nitrogen yang lainnya, dan yang terendah adalah aktinomyces (Streptomyces sp./I). 
Tabel 2. Penghitungan jumlah populasi mikroba pada inokulan yang tersimpan dan reaksi pelarutan fosfat yang ditandai dengan adanya pembentukan holozone $[\phi=1 \mathrm{~cm}$ $(+) ; 1,5 \mathrm{~cm}(++) ; 2 \mathrm{~cm}(+++)]$

\begin{tabular}{|c|c|c|c|c|c|c|}
\hline \multirow{2}{*}{ No } & \multirow{2}{*}{ Kode } & \multirow{2}{*}{ Bakteri yang dianalisa } & \multicolumn{2}{|c|}{ P0pulasi mikroba (sel/ml) } & \multicolumn{2}{|c|}{ Pembentukan holozon } \\
\hline & & & 0 Tahun $\left(10^{9}\right)$ & 4 Tahun $\left(10^{7}\right)$ & 0 Tahun & 4 Tahun \\
\hline 1 & $\mathrm{~B}$ & Azospirillum sp & 2 & 2 & ++ & ++ \\
\hline 2 & $\mathrm{C}$ & Azotobacter chroococcum & 1 & 2 & ++ & ++ \\
\hline 3 & $\mathrm{~A}$ & Azotobacter indicus & 3 & 3 & +++ & +++ \\
\hline 4 & $E$ & Azotobacter paspalii & 3 & 2 & ++ & ++ \\
\hline 5 & $\mathrm{D}$ & Bacillus panthothenticus & 3 & 3 & +++ & +++ \\
\hline 6 & $\mathrm{~F}$ & Bacillus megaterium & 3 & 3 & +++ & +++ \\
\hline 7 & $\mathrm{O}$ & Bacillus thuringiensis & 3 & 3 & +++ & +++ \\
\hline 8 & $\mathrm{~K}$ & Cellulomonas flavigena & 1 & 2 & ++ & ++ \\
\hline 9 & $\mathrm{R}$ & Ceratia sp & 1 & 3 & +++ & +++ \\
\hline 10 & G & Chromobacterium lividum & 3 & 3 & +++ & +++ \\
\hline 11 & $\mathrm{~S}$ & $\begin{array}{l}\text { Chromobacterium } \\
\text { violaceum }\end{array}$ & 3 & 3 & +++ & +++ \\
\hline 12 & $\mathrm{~N}$ & Citrobacter sp. & 1 & 2 & ++ & ++ \\
\hline 13 & $\mathrm{~T}$ & Flavobacterium breve & 2 & 3 & +++ & +++ \\
\hline 14 & $\mathrm{H}$ & Klebsiella aerogenes & 3 & 3 & +++ & +++ \\
\hline 15 & $P$ & $\begin{array}{l}\text { Nitromosomonas } \\
\text { mesentrica }\end{array}$ & 2 & 2 & ++ & ++ \\
\hline 16 & $\mathrm{~J}$ & Pseudomonas fluorescent & 3 & 3 & +++ & +++ \\
\hline 17 & $\mathrm{~L}$ & Rhizobium legurxinosarium & 3 & 3 & +++ & +++ \\
\hline 18 & Q & Spaerotilus natans & 2 & 2 & ++ & ++ \\
\hline 19 & $\mathrm{M}$ & Spirilum lipoferum & 1 & 2 & ++ & ++ \\
\hline 20 & $\mathrm{I}$ & Streptomyces sp. & 0,2 & 0,1 & + & + \\
\hline
\end{tabular}

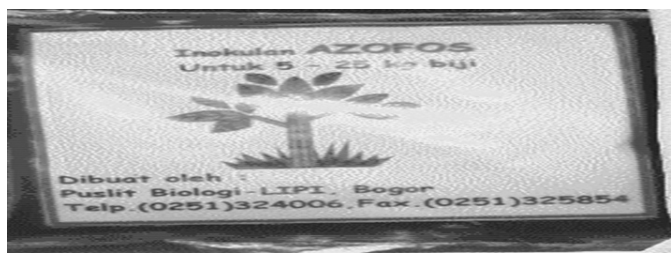

$1 a$

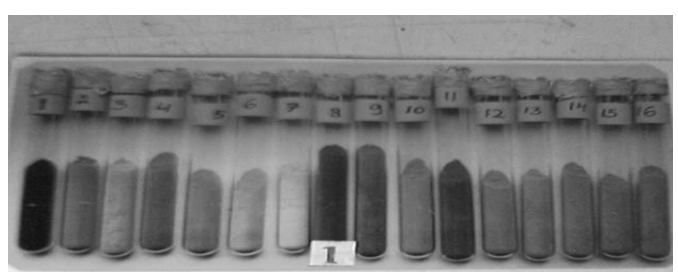

$1 \mathrm{~b}$

Gambar 1. Kemasan inokulan mikroba (AZZOFOR) yang telah tersimpan 4 tahun dalam lemari pendingin (1a) yang merupakan hasil isolasi dari tanah hutan Wamena (1b)

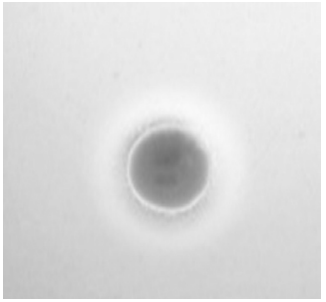

a

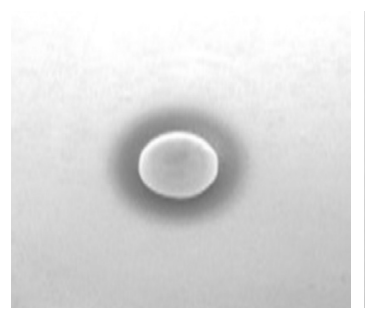

b

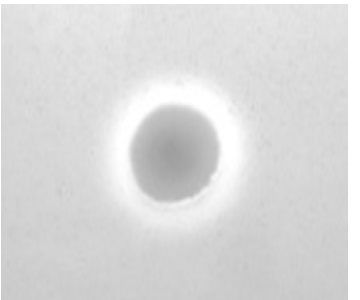

C

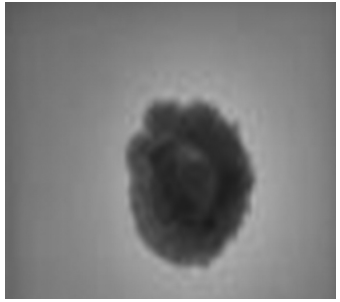

d

Gambar 2 Uji pelarutan fosfat oleh : mikroba BPNNS (a), BPNS (b), BPF (c), dan Aktinimisetes (d), ditandai oleh daerah bening (holozone area) disekitar koloni yang sedang tumbuh 
Orthofosfat dihasilkan dari pelarutan kalsium. Konsentrasi tertinggi dicapai oleh mikroba E, F, K pada inkubasi hari ke 33 dan konsentrasi paling tinggi dicapai oleh mikroba O inkubasi hari ke 3 dan 6 , sedangkan konsentrasi terendah dicapai oleh mikroba B inkubasi hari ke 15 (Gambar 3). biotransformasi elemen makro dan mikro seperti Mn, Zn, Cu dan Mo. Pelarutan elemen-elemen tersebut berpengaruh terhadap fatogenitas mikroba pathogen dan ketahanan tanaman terhadap penyakit ${ }^{16}$.

Fosfomonoesterase merupakan salah satu enzim fosfatase dari kelompok enzim

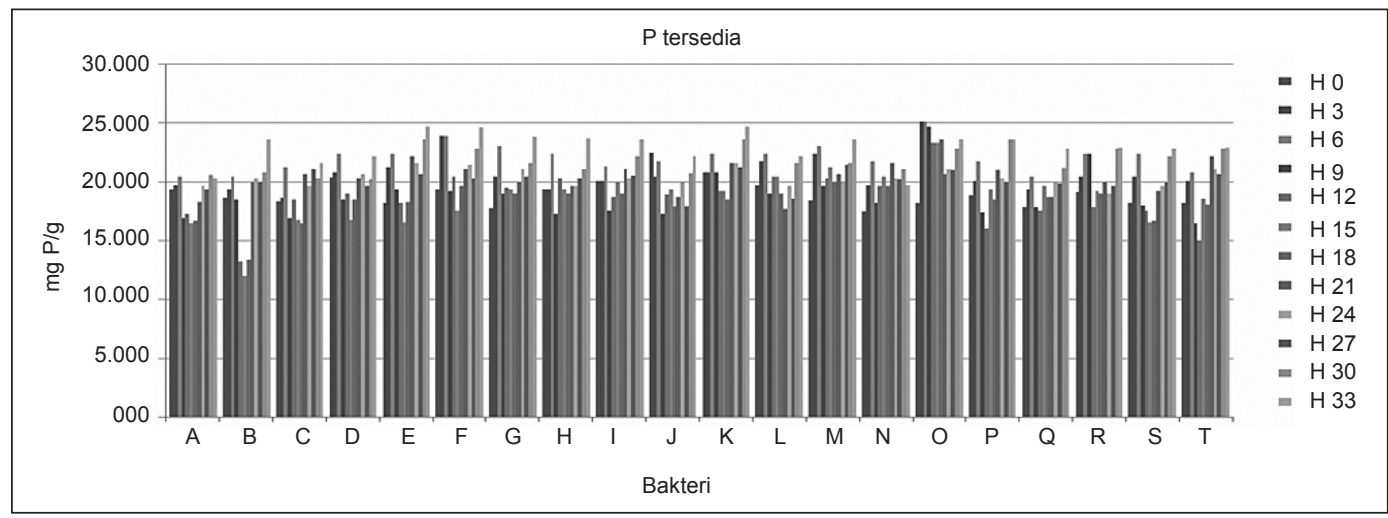

Gambar 3. Grafik pengukuran konsentrasi $\mathrm{P}$ tersedia selama inkubasi dari 0 hari $(\mathrm{H} 0)$ sampai 33 hari (H33) pada 20 jenis mikroba pelarut fosfat

Proses pelarutan fosfat melibatkan perubahan $\mathrm{pH}$, hal ini karena adanya sintetis senyawa organik yang dilepaskan kedalam medium, reaksi oksidasi reduksi, dan organik ligand kompetitor ${ }^{15}$. Konsentrasi tertinggi (Gambar 3) dan disertai turunnya $\mathrm{pH}$ (Gambar 4), ini menunjukkan bahwa mikroba $\mathrm{O}$ baik digunakan sebagai agen biofertilizer. Penurunan $\mathrm{pH}$ merupakan salah satu penyebab terjadinya pelarutan $\mathrm{Ca}$ fosfat menjadi orthosphosphat. Kemasaman tanah juga berpengaruh kepada proses hidrolase yang berfungsi menambat $\mathrm{H}_{2} \mathrm{O}$ dalam ikatan esterfosfat ${ }^{17}$. Enzim fosfatase merupakan komplek enzim terpenting di dalam tanah yang berfungsi melarutkan fosfat organik menjadi fosfat tersedia bagi tanaman. Enzim tersebut akan dihasilkan secara dominan pada kondisi ketersediaan fosfor rendah. Enzim fosfomonoesterase (PMEase) terdiri dari PMEase-asam dan basa. Oleh karenya di uji aktivitas PMEaseasam dan basanya dan hasilnya dapat dilihat pada Gambar 5 dan 6 . Hal ini untuk

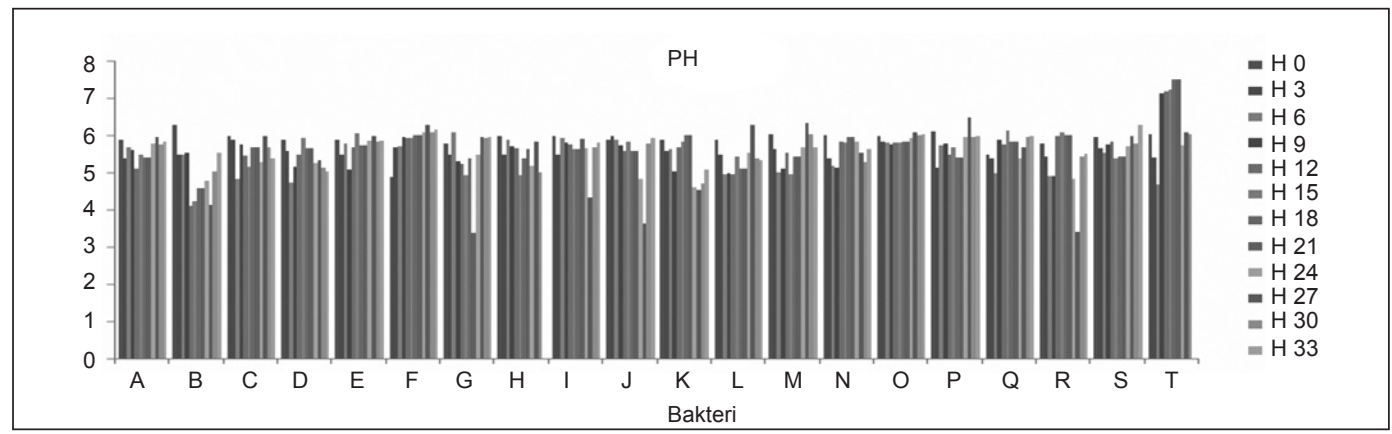

Gambar 4. Grafik dari kondisi pH selama inkubasi dari $0(\mathrm{H} 0)$ sampai $33(\mathrm{H} 33)$ hari pada 20 jenis mikroba pelarut fosfat 
mengantisipasi mikroba yang diperoleh dari tanah asam atau pada mikroorganisme dan hewan tanah serta PMEase-basa pada tanah basa atau pada jaringan tanaman ${ }^{18)}$.

Aktivitas enzim PMEase-asam dan basa meningkat selama inkubasi. Peningkatan aktivitas tersebut dapat terinduksi ketika jumlah $P$ terbatas dalam media tanam/ pertumbuhan mikroba, juga mencirikan akan tingginya kebutuhan $\mathrm{P}^{19)}$. Aktivitas PMEaseasam dan basa selama inkubasi 33 hari menghasilkan nilai tertinggi dan terendah (Tabel 3). Hasilnya menunjukan bahwa jenis mikroba B, C, E, K, M, N, P, dan $Q$ tidak pernah mencapai nilai tertinggi, sedangkan mikroba A, D, F, G, H, J, L, O, R, S, dan T mencapai nilai tertinggi selama inkubasi $(0$ hari - 33 hari). Mikroba I juga ternyata tidak pernah mencapai nilai tertinggi dan nilainya selalu lebih rendah dibandingkan mikroba lain. Ini menunjukkan bahwa mikroba A, D, F, G, H, J, L, O, R, S, dan T dapat memecah ikatan ester dari fosfat inorganik sehingga dapat memecah ikatan ester pada senyawa organik fosfat. Fosfat dibebaskan dari fosfomonoester melalui hidrolisis secara enzimatis oleh fosfomonoesterase ${ }^{20}$.

Glukosa yang terdapat dalam media pikovskaya selain digunakan mikroba untuk aktivitas PMEase asam dan basa juga akan terabsorbsi dan ditransfer ke dalam biomasa (Lampiran 1). Aktivitas konversi glukosa menjadi biomassa dikenal dengan nama "Yield Coefecient" berbeda pada masing - masing jenis mikroba ${ }^{21}$. Biomassa terbesar di capai oleh Mikroba F di hari ke 15

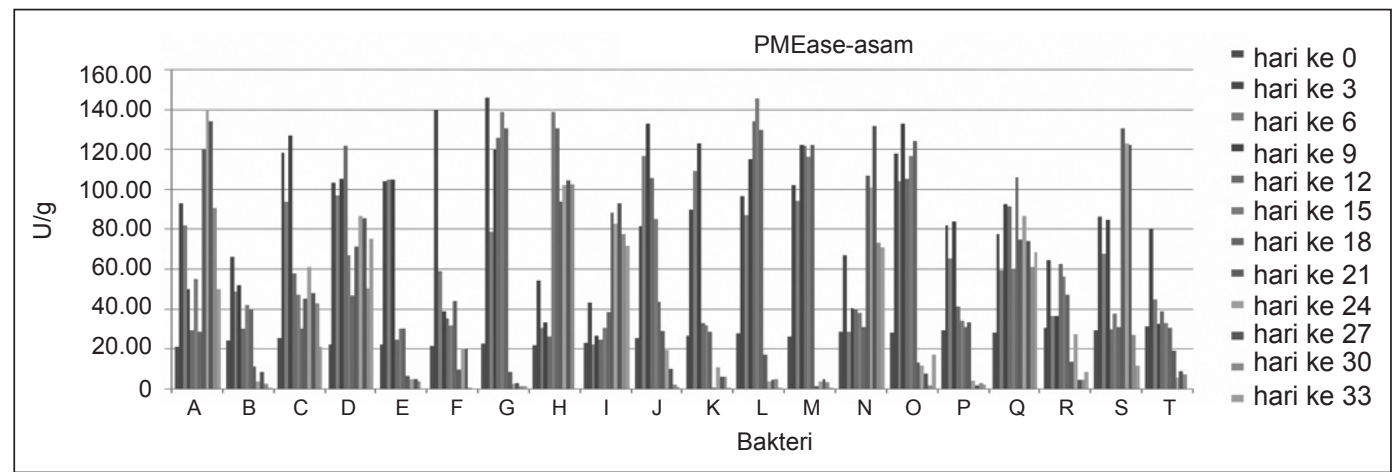

Gambar 5. Grafik aktivitas PMEase-asam selama inkubasi dari 0 hari ( $\mathrm{H0})$ sampai 33 hari (H33) pada 20 jenis mikroba pelarut fosfat

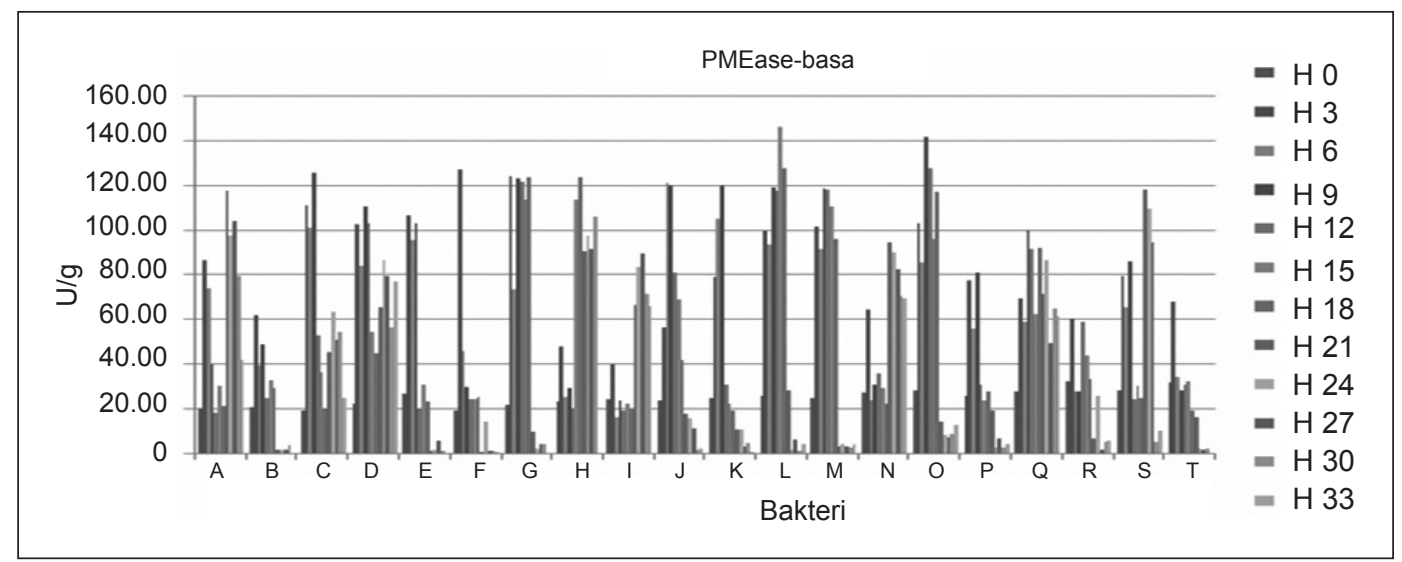

Gambar 6. Grafik aktivitas PMEase-basa selama inkubasi dari 0 hari (H0) sampai 33 hari (H33) pada 20 jenis mikroba pelarut fosfat 
Tabel 3. Rekapitulasi Aktivitas PMEase-asam dan basa tertinggi dan terendah oleh mikroba selama inkubasi 33 hari

\begin{tabular}{|c|c|c|c|c|}
\hline \multirow{2}{*}{ Hari ke } & \multicolumn{2}{|c|}{ PMEase-asam } & \multicolumn{2}{|c|}{ PMEase-basa } \\
\hline & Tertinggi (Mikroba) & Terendah (Mikroba) & Tetinggi (Mikroba) & Terendah (Mikroba) \\
\hline 0 & $\mathrm{R}, \mathrm{T}$ & A & $\mathrm{R}$ & $\mathrm{A}, \mathrm{B}, \mathrm{F}$ \\
\hline 3 & G & I & $\mathrm{F}$ & 1 \\
\hline 6 & $\mathrm{~J}$ & $\mathrm{I}, \mathrm{N}$ & $\mathrm{J}$ & $\mathrm{I}, \mathrm{T}$ \\
\hline 9 & $\mathrm{~J}, \mathrm{G}, \mathrm{O}$ & 1 & $\mathrm{O}$ & $\mathrm{I}, \mathrm{T}$ \\
\hline 12 & $\mathrm{~L}$ & $E$ & G,O & I \\
\hline 15 & $\mathrm{~L}$ & $\mathrm{I}, \mathrm{E}$ & $\mathrm{L}$ & $\mathrm{F}, \mathrm{I}, \mathrm{K}, \mathrm{P}, \mathrm{R}, \mathrm{S}, \mathrm{T}$ \\
\hline 18 & $\mathrm{G}, \mathrm{H}$ & $\mathrm{C}, \mathrm{K}$ & $\mathrm{G}, \mathrm{H}, \mathrm{L}$ & $\mathrm{C}, \mathrm{I}, \mathrm{K}, \mathrm{T}$ \\
\hline 21 & S & $\mathrm{E}, \mathrm{F}, \mathrm{G}, \mathrm{K}, \mathrm{M}$ & $A, S$ & $\mathrm{~F}$ \\
\hline 24 & A & $\mathrm{B}, \mathrm{E}, \mathrm{G}, \mathrm{LM}, \mathrm{P}, \mathrm{T}$ & $S$ & $\mathrm{~B}, \mathrm{E}, \mathrm{G}, \mathrm{L}, \mathrm{M}, \mathrm{P}, \mathrm{T}$ \\
\hline 27 & A & $\mathrm{E}, \mathrm{G}, \mathrm{K}, \mathrm{LM}, \mathrm{O}, \mathrm{P}, \mathrm{R}$ & A & $\mathrm{B}, \mathrm{F}, \mathrm{Q}, \mathrm{T}$ \\
\hline 30 & $\mathrm{H}$ & $\mathrm{B}, \mathrm{E}, \mathrm{F}, \mathrm{G}, \mathrm{J}, \mathrm{M}, \mathrm{O}, \mathrm{P}$ & $\mathrm{H}$ & $\mathrm{E}, \mathrm{F}, \mathrm{J}, \mathrm{L}, \mathrm{T}$ \\
\hline 33 & $\mathrm{D}$ & $\mathrm{B}, \mathrm{E}, \mathrm{F}, \mathrm{H}, \mathrm{J}, \mathrm{K}, \mathrm{L}, \mathrm{M}, \mathrm{T}$ & $\mathrm{D}$ & $\mathrm{B}, \mathrm{E}, \mathrm{F}, \mathrm{G}, \mathrm{H}, \mathrm{K}, \mathrm{T}$ \\
\hline
\end{tabular}

sampai hari ke 33 dan mungkin akan lebih jika inkubasinya diteruskan. Sedangkan biomassa paling rendah dihasilkan oleh mikroba T di hari ke 6 dan meningkat kembali di hari berikutnya. Biomassa mikroba dihitung untuk menentukan keberhasilan suatu mikroba dalam pertumbuhan dan persaingan dengan mikroba lain dan ratio biomassa ini akan menunjukkan perbedaan fisiologi dari masing - masing jenis mikroba, bermanfaat juga untuk membantu menggolongkan jenis dalam proses identifikasi.

\section{KESIMPULAN}

Percobaan aktivitas enzim pelarutan fosfat oleh mikroba efektif dalam kompos plus yang diisolasi dari tanah hutan Wamena dan telah tersimpan selama 4 tahun pada lemari pendingin dapat disimpulkan bahwa penyimpanan tersebut tidak banyak mempengaruhi efektivitas mikroba dalam aktivitas pelarutan enzim fosfatase. Seluruh mikroba yang diuji kelayakannya sebagai agen biofertilizer yang mempunyai efektivitas tertinggi adalah: Azotobacter indicus (A), Bacillus panthothenticus (D), Bacillus megaterium (F), Bacillus thuringiensis (O), Ceratia sp. (R), Chromobacterium lividum (G), Chromobacterium violaceum
(S), Flavobacterium breve (T), Klebsiella aerogenes (H), Pseudomonas fluorescent (J), Rhizobium legurxinosarium (L), dan terendah adalai Streptomyces sp.(I). Inokulan tersebut masih layak untuk digunakan membantu pertumbuhan tanaman di lahan marginal atau untuk merevegetasi lahan marginal dan juga untuk pertanian organik ramah lingkungan di daerah marginal dan pesisir pantai.

\section{Ucapan Terimakasih}

Penulis mengucapakan terimakasih kepada HJD Latupapua dan Maman Rahmansyah sebagai pimpinan proyek Potensi Sumber Daya Alam Wamena Papua, karena penelitian ini terlaksana atas biaya dari proyek tersebut.

\section{DAFTAR PUSTAKA}

1. Widawati, S., suliasih, H.J.D. Latupapua and S. Arwan. 2005. Biodiversity of soil Microbes from Rhizospora at Wamena Biological Garden (WBiG), Jayawijaya, Papua. Biodiversitas (6) $1:$ : 6-11.

2. Suliasih, H.J.D. Latupapua, and S. Widawati. 2005. The effectiveness of Microbial Inoculant Originated 
from Wamena Biological Garden and Compost Augmentation to Stimulate the Growth of Pterocarpus indicus Jacq. Gakuryoku vol.XI (3):12-15.

3. Sudiana, I. M. 2005. Teknologi Inovatif Interaksi Mikroba akar dan Leguminosa Untuk mempercepat revegetasi Das Citarum. Laporan Akhir Program Penelitian dan Pengembangan IPTEK Riset Kompetitif LIPI Tahun Anggaran 2005 (Unpublish)

4. Widawati S. 2005. Daya Pacu Aktivator Fungi Asal Kebun Biologi Wamena terhadap Kematangan dan Hara Kompos, serta kandungan Mikrobia Pelarut fosfat dan Penambat Nitrogen. Biodiversitas 6(4):238-241.

5. Widawati, S., Suliasih and Syaifudin. 2002. The application of compost plus on the growth of Orthosiphon aristatus.L. J.Biol.Indon. 3 (3) : $245-253$

6. Arwan S. dan S. Widawati. 2005. Pengaruh Kompos dan Berbagai Pupuk Hayati Terhadap Pertumbuhan dan Hasil Temu Lawak (Curcuma xanthorrhiza). Jurnal Biologi Indonesia III(9):371-378

7. Widawati, S., Suliasih, and H.J.D. Latupapua, 2005. The Application of soil microbes from Wamena Biological Garden (WBiG) as biofertilizer on purple eggplant (Solanum melongena L.). Gakuryoku XI(3):12-15:20-24

8. Widawati, S. dan suliasih.2006. Augmentasi bakteri pelarut fosfat (BPF) potensial sebagai pemacu pertumbuhan caysin (Brasica caventis Oed.) di tanah marginal. Biodiversitas 7(1):10-14.

9. Widawati, S. dan Suliasih, 2008. Pengaruh Kompos yang Diperkaya Bakteri Pelarut Fosfat Terhadap
Tanaman Kapri (Pisum sativum L.) dan Aktivitas Enzim Fosfatase dalam Tanah. Seminar Nasional. Pertemuan IImiah Tahunan Perhimpunan Mikrobiologi Indonesia. 22-23 Agustus 2008. UNSUD. Purwokerto.

10. Rao, N.S.Subba. 1994. Mikroba Tanah Dan Pertumbuhan Tanaman. Universitas Indonesia Press

11. Schinner, F.E., E. Kandeler, R. Ohlinger, R. Margesin 1996. Method in Soil Biology. Berlin : Springer-Verlag

12. Anderson, J.P.E. 1982. Methode of Soil Analysis. Madison, Wisconsin

13. Obaton, M. 1977. Effectivenes, Saprophitic and competitive Ability three properties of Rhizobium essensial for in-cresing the yield of inoculated Leumes p: 127-132.

14. Rachmiati, Y. 1995. Phosphate solubilizing bacteria dari rizozfer tanaman dan kemampuannya dalam melarutkan phosphate. Proseding Kongres Nasional VI HITI, Jakarta, 12-15 Desember 1995.

15. Cunningham, J. E., and C. Kuiack. 1992. Production of citric and oxalic acids and solubilization of calcium phosphate by Penicillium bilaii. Appl. Environ. Microbiol. 58:1451-1458.

16. Altomare, C., W.A. Norvell , T. Bjorkman , and G.E. Harman. 1999. Solubilization of Phosphates and Micronutrient by the Plant-Growth-Promoting and Biocontrol Fungus Trichoderma harzianum Rifai 1295-22. Applied and Environmental Microbiology 65 (7): 2926-2933.

17. Lehningger, A.L. 1990. Dasar dasar Biokimia. Maggy Thenawijaya, penerjemah; Terjemahan dari : Principle of Biochemistry. Jakarta : Erlangga. 
18. Schinner, F,E, E.,Kandeler, R . Ohlinger, R. Margesin .1996. Method in Soil Biology. Berlin : Springer-Verlag

19. Savin, M.C., H. Taylor, J.H. Görres, J.A. Amador. 2000. Seasonal variation in acid phosphatase activity as a function of landscape position and nutrient inputs. Agronomy Abstract 92:391
20. Ponmurugan, P., C. gopi. 2006. In vitro production of growth regulator and phosphatase activity by phosphate solubilizing bacteria. African Journal of Biothecnology 5(4):348-350.

21. Widawati S, A. Nurkanto dan I. M. Sudiana. 2008. Aktivitas pelarutan fosfat Aktinomisetes yang diisolasi dari Waigeo, Kepulauan Raja Ampat, Papua Barat. Biodiversitas 9(2):87-90. 
Lampiran 1. Biomasa 20 jenis mikroba pelarut fosfat selama inkubasi dari 0 hari $(\mathrm{H} 0)$ sampai 33 hari $(\mathrm{H} 33)$

\begin{tabular}{|c|c|c|c|c|c|c|c|c|c|c|c|c|}
\hline \multirow[b]{2}{*}{ Kode } & \multicolumn{12}{|c|}{ Pengamatan biomasa bakteri (g) } \\
\hline & $\begin{array}{l}\text { Hari } \\
\text { ke } 0\end{array}$ & $\begin{array}{l}\text { Hari } \\
\text { ke } 3\end{array}$ & $\begin{array}{l}\text { Hari } \\
\text { ke } 6\end{array}$ & $\begin{array}{l}\text { Hari } \\
\text { ke } 9\end{array}$ & $\begin{array}{c}\text { Hari } \\
\text { ke } 12\end{array}$ & $\begin{array}{c}\text { Hari } \\
\text { ke } 15\end{array}$ & $\begin{array}{c}\text { Hari } \\
\text { ke } 18\end{array}$ & $\begin{array}{c}\text { Hari } \\
\text { ke } 21\end{array}$ & $\begin{array}{c}\text { Hari } \\
\text { ke } 24\end{array}$ & $\begin{array}{c}\text { Hari } \\
\text { ke } 27\end{array}$ & $\begin{array}{c}\text { Hari } \\
\text { ke } 30\end{array}$ & $\begin{array}{l}\text { Hari } \\
\text { ke } 31\end{array}$ \\
\hline A & 0,04 & 0,09 & 0,02 & 0,02 & 0,04 & 0,06 & 0,08 & 0,08 & 0,08 & 0,07 & 0,07 & 0,07 \\
\hline B & 0,06 & 0,07 & 0,08 & 0,17 & 0,05 & 0,05 & 0,04 & 0,04 & 0,04 & 0,03 & 0,03 & 0,03 \\
\hline C & 0,07 & 0,07 & 0,07 & 0,06 & 0,03 & 0,02 & 0,05 & 0,05 & 0,05 & 0,05 & 0,05 & 0,05 \\
\hline D & 0,07 & 0,09 & 0,09 & 0,10 & 0,07 & 0,09 & 0,05 & 0,05 & 0,05 & 0,05 & 0,05 & 0,05 \\
\hline$E$ & 0,09 & 0,12 & 0,13 & 0,13 & 0,10 & 0,10 & 0,05 & 0,05 & 0,05 & 0,04 & 0,04 & 0,04 \\
\hline $\mathrm{F}$ & 0,02 & 0,02 & 0,02 & 0,08 & 0,09 & $0,21^{* *}$ & $0,21^{* *}$ & $0,21^{* *}$ & $0,21^{* *}$ & $0,21^{\text {** }}$ & $0,21^{* *}$ & $0,21^{* *}$ \\
\hline G & 0,08 & 0,07 & 0,08 & 0,08 & 0,07 & 0,08 & 0,07 & 0,07 & 0,07 & 0,06 & 0,06 & 0,06 \\
\hline $\mathrm{H}$ & 0,07 & 0,08 & 0,10 & 0,13 & 0,09 & 0,10 & 0,08 & 0,08 & 0,08 & 0,08 & 0,08 & 0,08 \\
\hline I & 0,06 & 0,09 & 0,12 & 0,07 & 0,09 & 0,12 & 0,10 & 0,10 & 0,10 & 0,09 & 0,09 & 0,09 \\
\hline $\mathrm{J}$ & 0,05 & 0,03 & 0,05 & 0,09 & 0,08 & 0,09 & 0,08 & 0,08 & 0,08 & 0,07 & 0,07 & 0,07 \\
\hline $\mathrm{K}$ & 0,03 & 0,04 & 0,12 & 0,12 & 0,11 & 0,13 & 0,13 & 0,13 & 0,13 & 0,12 & 0,12 & 0,12 \\
\hline L & 0,05 & 0,07 & 0,08 & 0,09 & 0,08 & 0,08 & 0,08 & 0,08 & 0,0 & 0,07 & 0,07 & 0,07 \\
\hline M & 0,04 & 0,07 & 0,07 & 0,08 & 0,07 & 0,07 & 0,08 & 0,08 & 0,08 & 0,07 & 0,07 & 0,07 \\
\hline $\mathrm{N}$ & 0,05 & 0,04 & 0,05 & 0,02 & 0,02 & 0,02 & 0,02 & 0,02 & 0,02 & 0,01 & 0,01 & 0,01 \\
\hline O & 0,03 & 0,02 & 0,05 & 0,06 & 0,02 & 0,07 & 0,09 & 0,09 & 0,09 & 0,08 & 0,08 & 0,08 \\
\hline $\mathrm{P}$ & 0,04 & 0,07 & 0,12 & 0,16 & 0,02 & 0,14 & 0,12 & 0,12 & 0,12 & 0,12 & 0,12 & 0,12 \\
\hline$Q$ & 0,08 & 0,04 & 0,08 & 0,09 & 0,08 & 0,03 & 0,06 & 0,06 & 0,06 & 0,06 & 0,06 & 0,06 \\
\hline $\mathrm{R}$ & 0,05 & 0,02 & 0,08 & 0,08 & 0,09 & 0,08 & 0,08 & 0,08 & 0,08 & 0,07 & 0,07 & 0,07 \\
\hline$S$ & 0,07 & 0,07 & 0,09 & 0,08 & 0,16 & 0,02 & 0,07 & 0,07 & 0,07 & 0,07 & 0,07 & 0,07 \\
\hline $\mathrm{T}$ & 0,05 & 0,02 & $0,01^{*}$ & 0,03 & 0,03 & 0,03 & 0,04 & 0,04 & 0,04 & 0,03 & 0,03 & 0,03 \\
\hline
\end{tabular}

Kode $\mathrm{A}-\mathrm{T}=$ Nama mikroba seperti pada Tabel 2 dan *

$=$ Biomasa terendah dan **

= Biomasa Tertinggi 